\title{
Natural Regeneration of Indigenous Tree Species in Broussonetia papyrifera Invaded Sites in Pra -Anum Forest Reserve
}

\author{
Moses Kwesi Yalley, ${ }^{1}$ Daniel Adusu $\mathbb{D}^{2},{ }^{2}$ Abdul-Rahman Bunyamin, ${ }^{3}$ Isaac Okyere, ${ }^{3}$ \\ and Austin Asare ${ }^{2}$ \\ ${ }^{1}$ Department of Forest Science, University of Energy and Natural Resources, Sunyani, Ghana \\ ${ }^{2}$ Department of Environmental Management, University of Energy and Natural Resources, Sunyani, Ghana \\ ${ }^{3}$ Department of Planning and Sustainability, University of Energy and Natural Resources, Sunyani, Ghana
}

Correspondence should be addressed to Daniel Adusu; adusudaniel@gmail.com

Received 4 December 2019; Revised 7 May 2020; Accepted 12 May 2020; Published 25 May 2020

Academic Editor: Qing Lai Dang

Copyright (c) 2020 Moses Kwesi Yalley et al. This is an open access article distributed under the Creative Commons Attribution License, which permits unrestricted use, distribution, and reproduction in any medium, provided the original work is properly cited.

\begin{abstract}
Broussonetia papyrifera invasion poses a serious threat to indigenous tree species in Ghana. Many conservation scientists therefore emphasize the need to control, manage, and possibly eradicate the species. However, attempts at control and management require adequate knowledge of its ecology and impact on invaded ecosystems. Employing a complete randomized design with twenty-four (24) $20 \mathrm{~m} \times 20 \mathrm{~m}$ plots, 12 each on invaded and uninvaded sites, this study assesses the indigenous species regeneration potential under Broussonetia papyrifera-invaded sites in the Pra-Anum forest reserve. The study provides evidence of the negative impact of Broussonetia on the regenerative capacity of the reserve, as 335 seedlings per $4800 \mathrm{~m}^{2}$ distributed over 43 species were recorded on the uninvaded site compared to 156 seedlings per $4800 \mathrm{~m}^{2}$ distributed over 31 species on the invaded site. The study, however, observed some level of resilience of species belonging to the Ulmaceae and Lecythidaceae families, as they appeared fairly represented on the invaded site. Floristic diversity was also observed to be negatively impacted by Broussonetia invasion as mean Shannon and Simpson index values of $2.39 \pm 0.71$ and $0.89 \pm 0.08$ and $1.39 \pm 0.24$ and $0.64 \pm 0.08$ were recorded on the uninvaded and invaded sites, respectively. Furthermore, the Broussonetia invasion compromised the productivity of the forest ecosystem as $4.9 \pm 1.61$ mean economic tree species per $400 \mathrm{~m}^{2}$ plot were recorded on the invaded site compared to $13.8 \pm 1.28$ per $400 \mathrm{~m}^{2}$ plot on the uninvaded site. The study, therefore, concludes that Broussonetia invasion poses a serious threat to the integrity and productivity of the Pra-Anum forest reserve. Consequently, the study recommends the control of the spread of the species to protect the integrity of the Pra-Anum forest reserve. Also, restoration efforts in invaded areas of the reserve could consider the use of native species belonging to the Ulmaceae and Lecythidaceae families as they appear to be resilient to Broussonetia invasion.
\end{abstract}

\section{Introduction}

Broussonetia papyrifera is a fast-growing broad-leaved woody perennial, belonging to the Moraceae family. It is native to Japan, Taiwan, and China, where they are cultivated for food, fiber, medicine, soil stabilization, erosion control, and paper production [1-3]. The ability of the species to thrive in the tropics, subtropics, and temperate regions has contributed to its spread beyond its native range [1]. It, therefore, currently occupies portions of farms and degraded forests in India, Japan, Europe, the USA, and some parts of
Africa [4]. Though bats, birds, and other wildlife which feed on its fruits have contributed to the dispersal of the seeds beyond its native range, their dispersal has largely been influenced by the deliberate introduction by governments to augment their natural resources base. It is currently ranked sixth among the worst invasive plants globally [5].

In Ghana, the species was introduced by the government in 1969 , to explore its potential for commercial paper production [1, 3]. The Forestry Research Institute of Ghana (FORIG), conducted field trials on the species, by the establishment of demonstration plots in the Afram Headwaters 
and Pra-Anum forest reserves in the dry and moist semideciduous forest zones of Ghana, respectively. The species has, however, spread beyond its origin of introduction and invaded farmlands and about $81,000 \mathrm{~km}^{2}$ of the closed forest cover in the Ashanti, Eastern, Bono, and Ahafo regions of Ghana [1, 3]. It has emerged to become one of the most serious invasive plant species in Ghana.

Since its introduction, the species has been observed to have impacted both positively and negatively on the forestry and agriculture sectors of Ghana. According to Owusu and Appiah [6] and Obour et al. [3], farmers in invaded communities use different parts of the plant for dying farm produce, fuelwood, fodder, medicine, and fencing. The authors also reported its potential for erosion control and soil nutrient improvement. On the other hand, the species has been reported to pose a serious threat to agriculture and biodiversity conservation [4, 7]. Broussonetia papyrifera invasion has negatively impacted farming activities in some farming communities in Ghana by significantly increasing farm maintenance cost [8]. The authors also reported that Broussonetia papyrifera invasion significantly influences vegetation characteristics in fragmented forest ecosystems around the country.

The challenges associated with Broussonetia papyrifera invasion in Ghana have received both national and global recognition, with many emphasizing the need to control, manage, and possibly eradicate the species. The Forestry Commission of Ghana, as part of its management attempts in 2006, acquired funding from the African Development Bank to conduct on-farm research aimed at recommending management strategies to deal with the species [9]. Farmers in invaded communities have also largely adopted measures such as slash and burn, herbicide application, and girdling to control the species [1]. These attempts have, however, yielded little results, as current field evidence suggests that the species continues to invade farms and forests in these areas.

The search for adequate control and management measures for Broussonetia papyrifera in Ghana has generated heightened debates among forest managers. This has attracted the attention and interest of researchers necessitating extensive studies on the species. These studies have largely focused on ecological characteristics that enhance its invasion (Kyereh et al.) [4], chemical composition and nutritive value [3], and occurrence and control [1]. However, according to Apetorgbor and Bosu [1], any attempt at the control and management of invasive species must be based on an adequate understanding of the ecology, impact on invaded ecosystem, and strategies for the restoration of invaded ecosystems. Though a few studies have attempted to assess the effects of the species on native vegetation, there are still contentions as different scientists have reported different effects of the species on native vegetation. For instance, while Agyeman [10] reported a positive effect of the species on indigenous species regeneration, Apetorgbor and Bosu [1] reported that the species impacts negatively on the abundance of indigenous species. Consequently, there is a need for more extensive studies on the species to establish its effect on native vegetation. The Pra-Anum forest reserve, which serves as one of the sites for the field trials in Ghana, presents a good opportunity for the assessment of the impact of the species on native vegetation; hence, it was selected as the study area. This study is expected to contribute to current scholarly debates on the effects of Broussonetia papyrifera invasion on indigenous tree species. It is further expected to shape policy decisions on the control and management of Broussonetia in invaded forest ecosystems and ultimately biodiversity conservation in forests Ghana.

\section{Materials and Methods}

2.1. Study Area Description. The Pra-Anum forest reserve falls within latitude $6^{\circ} 20^{\prime} 6^{\circ} 11^{\prime}$ North and longitude $1^{\circ} 7^{\prime}$ $1^{\circ} 16^{\prime}$ West [11]. It is within the jurisdiction of the Asante Akim South Municipal Assembly of Ashanti Region, but it is managed by Akim-Oda Forest District. It is bounded to the West by the Anum River and on the South and East by the Pra River (Figure 1). The reserve has an aggregate land area of about $132.87 \mathrm{~km}^{2}$ of which $3.10 \mathrm{~km}^{2}$ are occupied by admitted farms [11]. The Pra-Anum forest reserve falls within the moist semideciduous vegetation zone with about 230 tree species of which 67 are timber species [11]. The vegetation is dominated by Timber species such as Chrysophllum subnum, Aningeria robusta, Enthandrophragma candollei, Piptadeniastrum Africana, Turraeenthus African, Triplochiton scleroxylon, and Ceiba pentadra. Others species such as Albizia zygia, celtis mildbraedii, Celtis Zenkeri, Nesogordonia papyrierii, and Hannoa Klaineana are also well represented in the reserve. The reserve falls within the tropical humid Climatic Zone with mean annual rainfall and maximum temperature ranging between $1,250 \mathrm{~mm}$ and $1,500 \mathrm{~mm}$ and $27^{\circ} \mathrm{C}$ and $35^{\circ} \mathrm{C}$, respectively [11]. Geologically, the reserve is underlain by Brimian rock formation with granite and gneiss intrusive. There are also numerous small streams and rivers within the reserve which become marshy and swampy during the wet season [11].

2.2. Sampling Design. The study area was purposively stratified into two, to capture the different planting mixtures, which are the main focus of this study; i.e., Broussonetia papyrifera-invaded site and uninvaded site. In the two (2) sites, six (6) compartments were randomly selected comprising three (3) in the invaded site and three (3) in the uninvaded site. In each of the six (6) selected compartments, a $50 \mathrm{~m} \times 50 \mathrm{~m}$ sampling plot was randomly laid within which four (4) subplots, each of size $20 \mathrm{~m} \times 20 \mathrm{~m}$ was randomly laid for the sampling of saplings. Also, three (3) quadrants of sizes $5 \mathrm{~m} \times 5 \mathrm{~m}$ were randomly laid in each $20 \mathrm{~m} \times 20 \mathrm{~m}$ subplot for the sampling of seedlings. A total of twenty-four (24) $20 \mathrm{~m} \times 20 \mathrm{~m}$ subplots, comprising twelve (12) each for the invaded and the uninvaded sites, were used in assessing the regeneration of seedlings and saplings in Pra-Anum forest reserve.

2.3. Data Collection. In each of the $20 \mathrm{~m} \times 20 \mathrm{~m}$ subplots and $5 \mathrm{~m} \times 5 \mathrm{~m}$ quadrants, all seedlings $(<2 \mathrm{~cm} \cdot \mathrm{dbh})$ and saplings $(\geq 2 \mathrm{~cm} \cdot \mathrm{dbh}$ and $<10 \mathrm{~cm} \cdot \mathrm{dbh})$ were enumerated and 


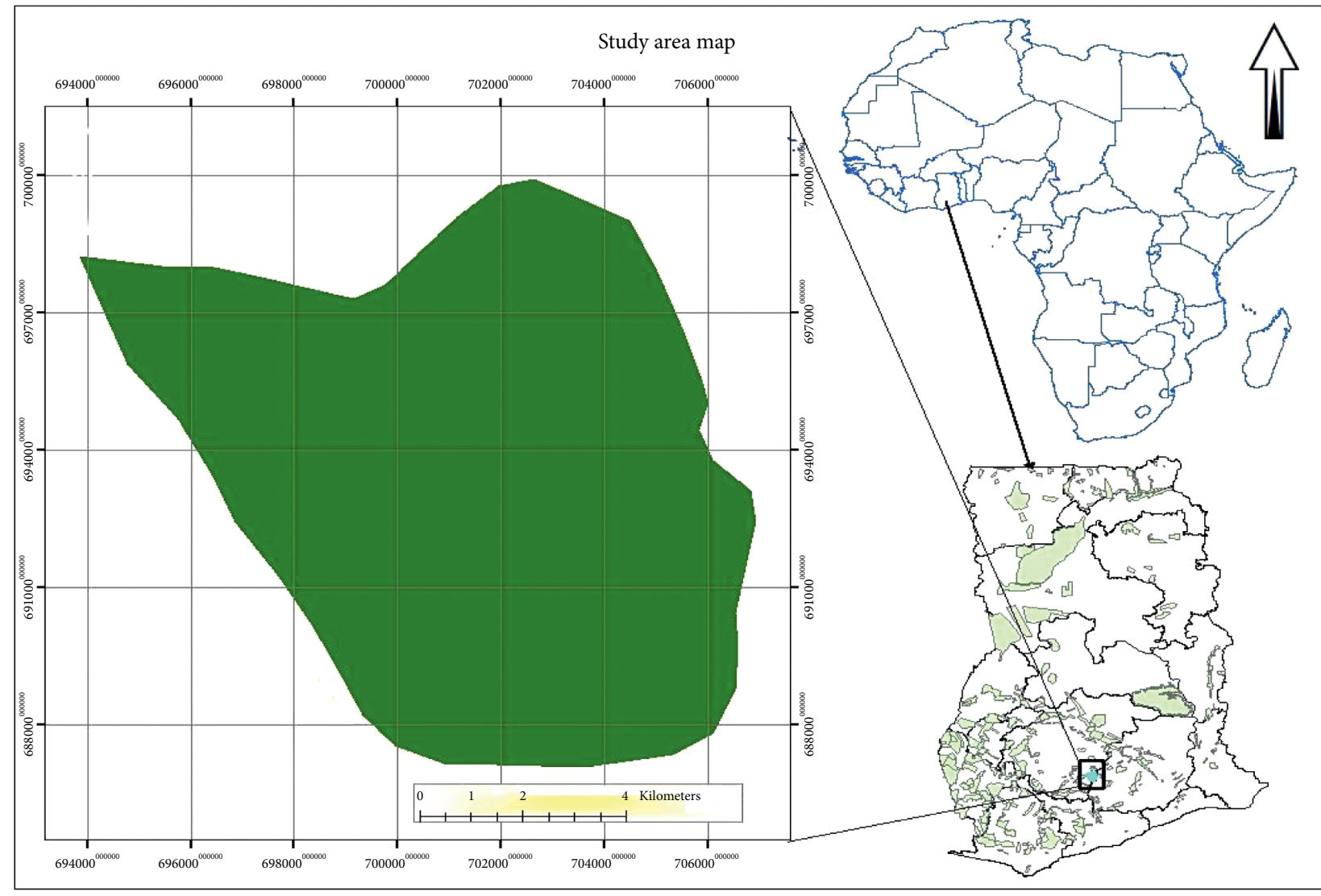

Legend

$\square$ Africa

$\square$ Forest reserves

Pra-anum forest reserve

Figure 1: Map of Pra-Anum forest reserve. Source: [11].

identified to species level with the assistance of a botanist from the Forest Research Institute of Ghana and photo guide for Forest Trees in Ghana [12]. The diameters at breast height $(\mathrm{DBH})$ of the seedlings and saplings were measured using digital calipers and diameter tape, respectively. The data from the two study sites were recorded on separate data sheets to prevent the mix up of data.

2.4. Data Analysis. The data collected from the various sampling plots were analyzed using MS Excel 2013 and SPSS version 20. Descriptive statistics for each of the sampled plots were generated using the SPSS software. The Shannon index $(H)$, Simpson index $(1-D)$, Shannon Evenness $(E)$, and Sorenson's Coefficient of similarity (SC) were estimated for the various sampled plots using MS Excel version 2013. The formulas for the various diversity indices used in the study are stated below:

$$
\text { Shannon index }(H)=-\sum P_{i} L_{n} P_{i} \text {, }
$$

where $P_{i}$ is the ratio of individual species in each plot $(n)$ to the total number of species in the plot $(N)$; that is, $P_{i}=(n / N)$ :

$$
\begin{aligned}
& \ln =\text { natural } \log , \\
& \Sigma=\text { sum of all figures },
\end{aligned}
$$

$$
\text { Simpson index }(D)=\sum P_{i}
$$

Shannon Evenness $(E)=\frac{H}{H_{\max }}$,

where $H_{\max }=\ln (N)$ and $N=$ number of species or species richness,

$$
\text { Sorenson's coefficient of similarity }(S)=\frac{2 * C}{2 C+S 1+S 2} \text {, }
$$

where $S=$ Sorenson index of similarity, $C=$ number of species the canopies have in common, $S 1=$ total number of species in the uninvaded site, and $S 2=$ total number of species in the invaded site.

The mean species frequencies and diversity index values of the various sampled plots were subjected to one-way analysis of variance (ANOVA) test at $5 \%$ probability level to 
determine the differences between the two study sites. The results are presented in tables for easy interpretation.

\section{Results and Discussion}

3.1. Composition of Naturally Regenerated Tree Species on Study Sites. The results of the study revealed differences in species composition between the two study sites. A total of forty-seven (47) plant species belonging to twenty-one (21) different families were identified on both sites. Out of this number, sixteen (16) of the species were peculiar to the uninvaded site while four (4) were peculiar to the invaded site. The remaining twenty-seven (27) species were common to both sites (Table 1). In terms of species count, the uninvaded site recorded a higher number (335) of indigenous tree seedlings and saplings per $4800 \mathrm{~m}^{2}$ compared to the invaded site, which recorded only 156 per $4800 \mathrm{~m}^{2}$. An interspecies comparison between the two study sites also revealed that apart from Alstonia boneiii, Celtis adolfi-friderici, Cola gigantean, Glyphaea brevis, Kigelia Africana, Napoleonaea vogelii, Pterygota macrocarpa, and Microdesmis puberula, where the invaded site recorded a higher species composition compared to the uninvaded site, the uninvaded site generally recorded a higher species composition. The dominant species in the uninvaded site were Afzelia hymenocardia, Diospyros sanza-minika, Sterculia rhinopetala, Turraeanthus africanus, Celtis mildbraedii, and Celtis zenkeri with species composition of 13.1, 11.6, 6.9, 6.9, 6.3, and $6.3 \%$, respectively. The least dominant species recorded in the uninvaded site were Aidia genipiflora, Antiaris toxicaria, Berlinia confusa, Berlinia occidentalis, Funtumia elastica, Kigelia Africana, and Pterygota macrocarpa which species composition of $0.3 \%$ each. However, the dominant species in the invaded site were Celtis adolf-friderici, Napoleonaea vogelii, Celtis mildbraedii, Alstonia booneii, and Diospyros sanza-minika with species composition of 15.4, 13.5, 9.6, 8.3, and 7.7\%, respectively. Amphimas pterocarpoides, Bombax buonopozense, Duguetia staudtii, Nesogordonia papaverifera, and Piptadeniastrum africanum were the least dominant among the species recorded on the invaded site with species composition of $0.6 \%$ each (Table 2 ). A one-way analysis of variance test on the mean species composition of the study sites revealed a significantly $(p=0.0)$ higher species composition in the uninvaded site $(27.9 \pm 2.4)$ per $400 \mathrm{~m}^{2}$ plot compared to the invaded site $(9.4 \pm 2.7)$. The differences in species composition on the two study sites may be attributed to several factors. The rapid reproduction, growth, dispersal, and regeneration potential of Broussonetia papyrifera, as well as its ability to withstand harsh environmental conditions, influenced its survival as the detriment of most native species were unable to adapt $[1,13,14]$. Under the logged conditions in the study area, Broussonetia papyrifera being a pioneering and highly competitive species, monopolized the forest canopy openings displacing the native vegetation. Even under competing conditions with native plant species, the allelopathic and high evapotranspiration ability of Broussonetia papyrifera facilitates the modification of site conditions, making it unsuitable for the growth of the native vegetation $[13,15]$.
Also, the fact that Broussonetia papyrifera fruits twice in a year and achieves reproductive maturity at a relatively small size, as well as its ability to regenerate from seeds, root suckers, and stumps, makes it more competitive than other native species [13]. This explains the high species composition on the uninvaded site compared to the invaded site. The species, therefore, pose a serious threat to forest ecosystems. Our results are consistent with the findings of Apetorgbor and Bosu [1] who reported that Broussonetia papyrifera invasion has the capacity to reduce the composition of some native species by suppressing their regeneration. Kyereh et al. [4] also reported that the Broussonetia papyrifera invasion is a major threat to native species regeneration and ecological succession in Ghana's forest ecosystems. However, the higher abundance of species such as Alstonia booneiii, Celtis adolfi-friderici, Cola gigantean, and Napoleonaea vogelii on the invaded site compared to the uninvaded site reveals that the Broussonetia papyrifera invasion does not suppress all native species. This is also consistent with the findings of Agyeman et al. [10] and Abugre et al. [16] who have reported that Broussnetia papyrifera does not suppress the regeneration of some shade-tolerant species.

\subsection{Family Distribution of Naturally Regenerated Tree Species} on Study Sites. The uninvaded site recorded 20 families, while the invaded site recorded 16 families. Out of the total number of families recorded on both sites, five (5) were peculiar to the uninvaded site, while only one (1) was peculiar to the invaded site. The remaining 15 families were common to both sites. The dominant families in the uninvaded site were Fabaceae, Malvaceae, and Meliaceae recording 9 (20.9\%), 8 (18.6), and 6 (14.0\%) species, respectively, per $4800 \mathrm{~m}^{2}$ while the least dominant families were Anacardiaceae, Bignoniaceae, Ebenaceae, Pandaceae, and Tiliaceae contributing $1(2.3 \%)$ species each. On the other hand, the most dominant families on the invaded site were Malvaceae and Fabaceae recording 6 (19.4\%) and 5 (16.1\%) species, respectively, per $4800 \mathrm{~m}^{2}$ while Anacardiaceae, Combretaceae, Rubiaceae, and Tiliaceae recorded $1(3.2 \%)$ species each. However, in terms of abundance, the Fabaceae, Meliaceae, Malvaceae, Ulmaceae, and Ebenaceae were the most dominant families on the uninvaded site recording 69 (20.6\%), 55 (16.4\%), 51 (14.9\%), 49 (14.6\%), and $39(11.6 \%)$ plants, respectively. Dominant species under these families were Diospyros sanza-minika, Turraeanthus africanus, Sterculia rhinopetala, Celtis mildbraedii, and Celtis zenkeri with 39 (11.6\%), 23 (6.9\%), 23 (6.9\%), 21 (6.3\%), and $21(6.3 \%)$ plants, respectively. The least dominant families in this site were Bignoniaceae, Moraceae, Rubiaceae, and Tiliaceae which recorded 1 (0.3\%) plant each. On the other hand, the most dominant families on the invaded site were Ulmaceae, Malvaceae, Lecythidaceae, Apocynaceae, and Fabaceae with 43 (27.6\%), 25 (16\%), 21 (13.5\%), 14 (9\%), and $12(7.7 \%)$ plants, respectively. Species that dominated under these families in this site were Celtis adolfi-friderici, Napoleonaea vogelii, Celtis mildbraedii, Alstonia bonai, and Cola gigantean with 24 (15.4\%), 21 (13.5\%), 15 (9.6), 13 (8.3\%), 
Table 1: Species distribution on the study sites.

\begin{tabular}{|c|c|c|}
\hline Species unique to the invaded site & Species unique to the uninvaded site & Species common to both sites \\
\hline $\begin{array}{l}\text { Aningeria robusta } \\
\text { Lannea welwitschii } \\
\text { Nauclea diderrichii } \\
\text { Terminalia ivorensis }\end{array}$ & $\begin{array}{c}\text { Aidia genipiflora } \\
\text { Antiaris toxicaria } \\
\text { Berlinia confusa } \\
\text { Berlinia occidentalis } \\
\text { Carapa procera } \\
\text { Ceiba pentandra } \\
\text { Cylicodiscus gabunensis } \\
\text { Distemonanthus benthamianus } \\
\text { Entandrophragma cylindricum } \\
\text { Mammea africana } \\
\text { Mansonia altissima } \\
\text { Memecylon lateriflorum } \\
\text { Pycnanthus angolensis } \\
\text { Ricinodendron heudelotii } \\
\text { Spondias mombin } \\
\text { Trichilia tessmanni }\end{array}$ & $\begin{array}{c}\text { Afzelia hymenocardia } \\
\text { Alstonia boonai } \\
\text { Amphimas pterocarpoides } \\
\text { Aningeria altissima } \\
\text { Baphia nitida } \\
\text { Blighia sapida } \\
\text { Bombax buonopozense } \\
\text { Celtis adolfi-friderici } \\
\text { Celtis mildbraedii } \\
\text { Celtis zenkeri } \\
\text { Cola gigantea } \\
\text { Diospyros sanza-minika } \\
\text { Duguetia staudtii } \\
\text { Entandrophragma angolense } \\
\text { Funtumia elastica } \\
\text { Glyphaea brevis } \\
\text { Griffonia simplicifolia } \\
\text { Kigelia africana } \\
\text { Napoleonaea vogelii } \\
\text { Nesogordonia papaverifera } \\
\text { Piptadeniastrum africanum } \\
\text { Pterygota macrocarpa } \\
\text { Microdesmis puberula } \\
\text { Sterculia rhinopetala } \\
\text { Trichilia monadelpha } \\
\text { Triplochiton scleroxylon } \\
\text { Turraeanthus africanus }\end{array}$ \\
\hline
\end{tabular}

and 11 (7.1\%) plants, respectively. The Apocynaceae, Combretaceae, and Rubiaceae families recorded 1 (0.6\%) plant each in the invaded site (Table 3 ). Our results are, to some extent, consistent with other studies by Addo-Fordjour et al. [13] who reported Ulmaceae as one of the dominant families in Broussonetia papyrifera invaded sites in the moist semideciduous forest zone of Ghana. The authors also reported that Celtis species are one of the most dominant species in Broussonetia papyrifera invaded sites which are also consistent with the findings of this study (Table 4).

\subsection{Naturally Regenerated Economic Timber Species on Study} Sites. The study further revealed that, out of the forty-seven (47) species identified in both sites, twenty-seven (27) were high economic value timber species. With the exception of Alstonia bonai, Aningeria robusta, Nauclea diderrichii, and Terminalia ivorensis, where the invaded site recorded a higher number of species compared to the uninvaded site, the uninvaded site generally recorded higher numbers of economic tree species. While the uninvaded sites recorded a total of 166 economic timber species distributed over twenty-four (24) different species, the invaded site recorded only 60 timber species seedlings distributed over 16 species (Table 5). The uninvaded and invaded sites recorded $13.8 \pm 1.28$ and $4.9 \pm 1.61$ mean economic tree species, respectively, per $400 \mathrm{~m}^{2}$ plot. The mean values of economic tree species on both study sites were subjected to an analysis of variance test, which revealed a significant difference $(p=0.00)$ in economic tree species between the two study sites. This result indicates that Broussonetia invasion is a limiting factor to the natural regeneration of indigenous tree species, particularly economic tree species [13]. Most of these native plants are species with high economic value; hence by suppressing their regeneration and growth, Broussonetia reduces the general productive capacity of the forests. The finding is consistent with other studies that have reported that Broussonetia papyrifera invasion does not only compromise species diversity but also the productivity of the forest ecosystems [14].

3.4. Conservation Star Rating of Naturally Regenerated Tree Species on Study Sites. Conservation star rating has become an important component of ecological studies due to their capacity to draw conservation attention by valuating species based on their distribution and level of vulnerability. According to Hawthorne et al. [17], plant species in Ghana can be classified as green, pink, red, scarlet, blue, and gold or black stars in increasing order of conservation priority. The presence of high rated star species in a forest, therefore, indicates the ecological value of the forest and the need for conservation [18]. The species identified on the two study sites were distributed among five different conservation star ratings, i.e., black, green, pink, red, and scarlets. On the uninvaded site, a majority 22 (51\%) of the naturally regenerating plant species belonged to the green star. This was followed by the pink, red, scarlet, and black stars recording $8(19 \%), 6(14 \%), 5(12 \%)$ and $2(5 \%)$ species respectively per $4800 \mathrm{~m}^{2}$. The blue and gold stars recorded no 
TABLE 2: Naturally regenerated tree species on study sites.

\begin{tabular}{|c|c|c|c|c|c|c|}
\hline \multirow{2}{*}{ Species } & \multirow{2}{*}{ Families } & \multirow{2}{*}{ Star ratings } & \multicolumn{2}{|c|}{ Uninvaded site } & \multicolumn{2}{|c|}{ Invaded site } \\
\hline & & & Frequency & $\%$ & Frequency & $\%$ \\
\hline Afzelia hymenocardia & Fabaceae & Red & 44 & 13.1 & 9 & 5.8 \\
\hline Aidia genipiflora & Rubiaceae & Green & 1 & 0.3 & 0 & 0.0 \\
\hline Alstonia boonai & Apocynaceae & Green & 8 & 2.4 & 13 & 8.3 \\
\hline Amphimas pterocarpoides & Fabaceae & Green & 6 & 1.8 & 1 & 0.6 \\
\hline Aningeria altissima & Sapotaceae & Red & 12 & 3.6 & 2 & 1.3 \\
\hline Aningeria robusta & Sapotaceae & Pink & 0 & 0.0 & 3 & 1.9 \\
\hline Antiaris toxicaria & Moraceae & Pink & 1 & 0.3 & 0 & 0.0 \\
\hline Baphia nitida & Fabaceae & Green & 7 & 2.1 & 0 & 0.0 \\
\hline Berlinia confusa & Fabaceae & Green & 1 & 0.3 & 0 & 0.0 \\
\hline Berlinia occidentalis & Fabaceae & Black & 1 & 0.3 & 0 & 0.0 \\
\hline Blighia sapida & Sapindaceae & Green & 8 & 2.4 & 3 & 1.9 \\
\hline Bombax buonopozense & Malvaceae & Pink & 2 & 0.6 & 1 & 0.6 \\
\hline Carapa procera & Meliaceae & Green & 4 & 1.2 & 0 & 0.0 \\
\hline Ceiba pentandra & Malvaceae & Green & 1 & 0.3 & 0 & 0.0 \\
\hline Celtis adolfi-friderici & Ulmaceae & Green & 7 & 2.1 & 24 & 15.4 \\
\hline Celtis mildbraedii & Ulmaceae & Green & 21 & 6.3 & 15 & 9.6 \\
\hline Celtis zenkeri & Ulmaceae & Green & 21 & 6.3 & 4 & 2.6 \\
\hline Cola gigantea & Malvaceae & Green & 6 & 1.8 & 11 & 7.1 \\
\hline Cylicodiscus gabunensis & Fabaceae & Pink & 2 & 0.6 & 0 & 0.0 \\
\hline Diospyros sanza-minika & Ebenaceae & Pink & 39 & 11.6 & 12 & 7.7 \\
\hline Distemonanthus benthamianus & Fabaceae & Red & 2 & 0.6 & 0 & 0.0 \\
\hline Duguetia staudtii & Annonaceae & Green & 2 & 0.6 & 1 & 0.6 \\
\hline Entandrophragma angolense & Meliaceae & Scarlet & 11 & 3.3 & 2 & 1.3 \\
\hline Entandrophragma cylindricum & Meliaceae & Scarlet & 2 & 0.6 & 0 & 0.0 \\
\hline Funtumia elastica & Apocynaceae & Green & 1 & 0.3 & 1 & 0.6 \\
\hline Glyphaea brevis & Tiliaceae & Green & 1 & 0.3 & 2 & 1.3 \\
\hline Griffonia simplicifolia & Fabaceae & Green & 4 & 1.2 & 1 & 0.6 \\
\hline Kigelia africana & Bignoniaceae & Green & 1 & 0.3 & 2 & 1.3 \\
\hline Lannea welwitschii & Anacardiaceae & Green & 0 & 0.0 & 2 & 1.3 \\
\hline Mammea africana & Guttiferae & Blue & 2 & 0.6 & 0 & 0.0 \\
\hline Mansonia altissima & Malvaceae & Red & 2 & 0.6 & 0 & 0.0 \\
\hline Memecylon lateriflorum & Melastomataceae & Green & 14 & 4.2 & 0 & 0.0 \\
\hline Napoleonaea vogelii & Lecythidaceae & Green & 11 & 3.3 & 21 & 13.5 \\
\hline Nauclea diderrichii & Rubiaceae & Scarlet & 0 & 0.0 & 1 & 0.6 \\
\hline Nesogordonia papaverifera & Malvaceae & Pink & 6 & 1.8 & 1 & 0.6 \\
\hline Piptadeniastrum africanum & Fabaceae & Red & 2 & 0.6 & 1 & 0.6 \\
\hline Pterygota macrocarpa & Malvaceae & Scarlet & 1 & 0.3 & 4 & 2.6 \\
\hline Microdesmis puberula & Pandaceae & Scarlet & 2 & 0.6 & 4 & 2.6 \\
\hline Pycnanthus angolensis & Myristicaceae & Red & 2 & 0.6 & 0 & 0.0 \\
\hline Ricinodendron heudelotii & Euphorbiaceae & Pink & 5 & 1.5 & 0 & 0.0 \\
\hline Spondias mombin & Anacardiaceae & Green & 2 & 0.6 & 0 & 0.0 \\
\hline Sterculia rhinopetala & Malvaceae & Pink & 23 & 6.9 & 2 & 1.3 \\
\hline Terminalia ivorensis & Combretaceae & Red & 0 & 0.0 & 1 & 0.6 \\
\hline Trichilia monadelpha & Meliaceae & Green & 12 & 3.6 & 3 & 1.9 \\
\hline Trichilia tessmanni & Meliaceae & Green & 3 & 0.9 & 0 & 0.0 \\
\hline Triplochiton scleroxylon & Malvaceae & Scarlet & 9 & 2.7 & 6 & 3.8 \\
\hline Turraeanthus africanus & Meliaceae & Pink & 23 & 6.9 & 3 & 1.9 \\
\hline Total & & & 335 & & 156 & \\
\hline
\end{tabular}

Source: authors construct (2019).

species on this site. Similarly, in the invaded site majority 15 (50\%) of the plant species belonged to the green star. This was followed by the pink, scarlet and red stars with $6(20 \%)$, $5(17 \%)$, and $4(13 \%)$ species, respectively. No species belonging to the black, blue, and gold stars were however recorded on this site (Table 6). The high composition of green and red star species under both study sites could be attributed to the dominance of these species in the forest ecosystem of Ghana [12]. The rarity of blue and gold star species (high conservation concern) on both study sites is an indication of the high level of degradation in the study area. Our results are consistent with the findings of Adusei [19] who reported the rarity of blue and black star species in a study conducted in the moist semideciduous forest zone of Ghana. However, the fact that some black stars species were recorded on the uninvaded site while none was recorded on 
TABLE 3: Family distribution of naturally regenerated tree species on study sites.

\begin{tabular}{|c|c|c|c|c|}
\hline \multirow{2}{*}{ Family } & \multicolumn{2}{|c|}{ Uninvaded site } & \multicolumn{2}{|c|}{ Invaded site } \\
\hline & Frequency & $\%$ & Frequency & $\%$ \\
\hline Anacardiaceae & 2 & 0.6 & 2 & 1.3 \\
\hline Annonaceae & 2 & 0.6 & 1 & 0.6 \\
\hline Apocynaceae & 9 & 2.7 & 14 & 9.0 \\
\hline Bignoniaceae & 1 & 0.3 & 2 & 1.3 \\
\hline Combretaceae & 0 & 0.0 & 1 & 0.6 \\
\hline Ebenaceae & 39 & 11.6 & 12 & 7.7 \\
\hline Euphorbiaceae & 5 & 1.5 & 0 & 0.0 \\
\hline Fabaceae & 69 & 20.6 & 12 & 7.7 \\
\hline Guttiferae & 2 & 0.6 & 0 & 0.0 \\
\hline Lecythidaceae & 11 & 3.3 & 21 & 13.5 \\
\hline Malvaceae & 50 & 14.9 & 25 & 16.0 \\
\hline Melastomataceae & 14 & 4.2 & 0 & 0.0 \\
\hline Meliaceae & 55 & 16.4 & 8 & 5.1 \\
\hline Moraceae & 1 & 0.3 & 0 & 0.0 \\
\hline Myristicaceae & 2 & 0.6 & 0 & 0.0 \\
\hline Pandaceae & 2 & 0.6 & 4 & 2.6 \\
\hline Rubiaceae & 1 & 0.3 & 1 & 0.6 \\
\hline Sapindaceae & 8 & 2.4 & 3 & 1.9 \\
\hline Sapotaceae & 12 & 3.6 & 5 & 3.2 \\
\hline Tiliaceae & 1 & 0.3 & 2 & 1.3 \\
\hline Ulmaceae & 49 & 14.6 & 43 & 27.6 \\
\hline
\end{tabular}

Source: authors construct (2019).

TABLE 4: Family distribution of species on the study sites.

\begin{tabular}{|c|c|c|}
\hline Families Unique to the invaded site & Families unique to the uninvaded site & Families common to both site \\
\hline Combretaceae & $\begin{array}{c}\text { Euphorbiaceae } \\
\text { Guttiferae } \\
\text { Melastomataceae } \\
\text { Moraceae } \\
\text { Myristicaceae }\end{array}$ & $\begin{array}{c}\text { Anacardiaceae } \\
\text { Annonaceae } \\
\text { Apocynaceae } \\
\text { Bignoniaceae } \\
\text { Ebenaceae } \\
\text { Fabaceae } \\
\text { Lecythidaceae } \\
\text { Malvaceae } \\
\text { Meliaceae } \\
\text { Pandaceae } \\
\text { Rubiaceae } \\
\text { Sapindaceae } \\
\text { Sapotaceae } \\
\text { Tiliaceae } \\
\text { Ulmaceae }\end{array}$ \\
\hline
\end{tabular}

the invaded site suggests that the Broussonetia invasion may also suppress the regeneration of species with high conservation value. Conservation action in Ghana must, therefore, prioritize the control and management of Broussonetia to conserve biological resources in the country.

3.5. Species Diversity on Study Sites. The results of diversity indices estimations revealed a generally higher species diversity in the uninvaded site compared to the Broussonetia papyrifera-invaded sites. Mean Shannon index values of $2.39 \pm 0.71$ and $1.39 \pm 0.24$ were recorded for the uninvaded and invaded sites, respectively. Also, the uninvaded site recorded a mean Simpson's index of $0.89 \pm 0.08$ while the invaded site recorded a Simpson's index of $0.64 \pm 0.08$ (Table 7). The mean values of the indices for the two study sites were subjected to an analysis of variance test which revealed a significant difference $(p<0.05)$ between the two study sites in both cases. This indicates that the Broussonetia papyrifera invasion compromises the diversity of indigenous plant species within the forest ecosystem. There is, therefore, the need to control the species to protect the integrity of the forest. According to Addo-Fordjour et al. [13], the environmental conditions of disturbed forests favour the growth of invasive species such as Broussonetia papyrifera and exert negative impacts on native plant species. Malik and Husain [5] also reported that the vigorous and extensive growth, as well as the habitat degradation properties of Broussonetia 
TABLE 5: Naturally regenerated economic tree species on study sites.

\begin{tabular}{|c|c|c|c|c|}
\hline \multirow{2}{*}{ Species } & \multicolumn{2}{|c|}{ Uninvaded site } & \multicolumn{2}{|c|}{ Invaded site } \\
\hline & Frequency & $\%$ & Frequency & $\%$ \\
\hline Alstonia boonai & 8 & 4.8 & 13 & 21.7 \\
\hline Amphimas pterocarpoides & 6 & 3.6 & 1 & 1.7 \\
\hline Aningeria altissima & 12 & 7.2 & 2 & 3.3 \\
\hline Aningeria robusta & 0 & 0.0 & 3 & 5.0 \\
\hline Antiaris toxicaria & 1 & 0.6 & 0 & 0.0 \\
\hline Berlinia confusa & 1 & 0.6 & 0 & 0.0 \\
\hline Berlinia occidentalis & 1 & 0.6 & 0 & 0.0 \\
\hline Bombax buonopozense & 2 & 1.2 & 1 & 1.7 \\
\hline Ceiba pentandra & 1 & 0.6 & 0 & 0.0 \\
\hline Celtis mildbraedii & 21 & 12.7 & 15 & 25.0 \\
\hline Celtis zenkeri & 21 & 12.7 & 4 & 6.7 \\
\hline Cylicodiscus gabunensis & 2 & 1.2 & 0 & 0.0 \\
\hline $\begin{array}{l}\text { Distemonanthus } \\
\text { benthamianus }\end{array}$ & 2 & 1.2 & 0 & 0.0 \\
\hline Entandrophragma angolense & 11 & 6.6 & 2 & 3.3 \\
\hline $\begin{array}{l}\text { Entandrophragma } \\
\text { cylindricum }\end{array}$ & 2 & 1.2 & 0 & 0.0 \\
\hline Mammea africana & 2 & 1.2 & 0 & 0.0 \\
\hline Mansonia altissima & 2 & 1.2 & 0 & 0.0 \\
\hline Nauclea diderrichii & 0 & 0.0 & 1 & 1.7 \\
\hline Nesogordonia papaverifera & 6 & 3.6 & 1 & 1.7 \\
\hline Piptadeniastrum africanum & 2 & 1.2 & 1 & 1.7 \\
\hline Pterygota macrocarpa & 1 & 0.6 & 4 & 6.7 \\
\hline Pycnanthus angolensis & 2 & 1.2 & 0 & 0.0 \\
\hline Ricinodendron heudelotii & 5 & 3.0 & 0 & 0.0 \\
\hline Sterculia rhinopetala & 23 & 13.9 & 2 & 3.3 \\
\hline Terminalia ivorensis & 0 & 0.0 & 1 & 1.7 \\
\hline Triplochiton scleroxylon & 9 & 5.4 & 6 & 10.0 \\
\hline Turraeanthus africanus & 23 & 13.9 & 3 & 5.0 \\
\hline & 166 & & 60 & \\
\hline
\end{tabular}

Source: authors construct (2019).

TABLE 6: Conservation star rating of naturally regenerated tree species on study sites.

\begin{tabular}{lcccc}
\hline \multirow{2}{*}{ Star rating } & \multicolumn{2}{c}{ Uninvaded site } & \multicolumn{2}{c}{ Invaded site } \\
& Frequency & $\%$ & Frequency & $\%$ \\
\hline Black & 2 & 5 & 0 & 0 \\
Green & 22 & 51 & 15 & 50 \\
Pink & 8 & 19 & 6 & 20 \\
Red & 6 & 14 & 4 & 13 \\
Scarlet & 5 & 12 & 5 & 17 \\
\hline
\end{tabular}

Source: authors construct (2019).

papyrifera, make the local environment unsuitable for the growth of other native plant species. It has, therefore, been widely reported to pose a serious threat to native floristic diversity conservation $[5,13,20]$. In a study in the Himalayan foothills scrub forest in Pakistan, Malik and Husain [5] observed a decrease in species diversity with the increasing dominance of B. papyrifera. Similarly, in a study on the occurrence and control of Broussonetia papyrifera in the moist semideciduous forest zone of Ghana, Apetorgbor and Bosu [1] also observed that invaded areas had lower species diversity compared to uninvaded portions of the forest.
TABle 7: Species diversity on study sites.

\begin{tabular}{ccccc}
\hline Vegetation type & $\begin{array}{c}\text { Shannon } \\
(H)\end{array}$ & Simpson $(1-D)$ & $\begin{array}{c}\text { Shannon } \\
(E)\end{array}$ \\
\hline \multirow{6}{*}{ Uninvaded } & Mean & 2.39 & 0.89 & 0.93 \\
Std. & 0.24 & 0.29 & 0.35 \\
& $\begin{array}{c}\text { deviation } \\
\text { Std. error }\end{array}$ & 0.71 & 0.08 & 0.01 \\
& Minimum & 1.90 & 0.80 & 0.90 \\
& Maximum & 2.70 & 0.90 & 1.00 \\
\hline \multirow{5}{*}{ Invaded } & Mean & 1.39 & 0.64 & 0.84 \\
& Std. & 0.82 & 0.26 & 0.27 \\
& deviation & & & \\
& Std. error & 0.24 & 0.08 & 0.08 \\
& Minimum & 0.00 & 0.00 & 0.00 \\
& Maximum & 2.70 & 0.90 & 1.00 \\
& $p$ value & 0.01 & 0.04 & 0.41 \\
\hline
\end{tabular}

Source: authors construct (2019).

TABLE 8: Sorenson's index of native species in study sites.

\begin{tabular}{lccc}
\hline $\begin{array}{l}\text { Species } \\
\text { status }\end{array}$ & $\begin{array}{c}\text { Uninvaded } \\
\text { site }\end{array}$ & $\begin{array}{c}\text { Invaded } \\
\text { site }\end{array}$ & $\begin{array}{c}\text { Sorensen's coefficient } \\
\text { (SC) }\end{array}$ \\
\hline $\begin{array}{l}\text { Unique } \\
\text { species }\end{array}$ & 16 & 4 & 0.73 \\
\hline $\begin{array}{l}\text { Shared } \\
\text { species }\end{array}$ & 27 & 27 & \\
\hline
\end{tabular}

Source: authors construct (2019).

However, the high mean Shannon evenness values recorded on the uninvaded $(0.93 \pm 0.01)$ and invaded $(0.84 \pm 0.08)$ sites as well as Sorenson's Coefficient (SC) value of 0.73 indicate that despite the differences in the species diversity observed on both sites, there is a high level of similarity among the species on the study sites (Tables 7 and 8). According to Kreb [21], SC values below 0.5 indicates dissimilarity of species composition between two sites while values greater than 0.5 indicates similarities in species composition between two sites. This result is consistent with the findings of Apetorgbor and Bosu [1] who also observed similarities in species on Broussonetia papyrifera-invaded and uninvaded plots in a study in the southern part of Ghana.

\section{Conclusion}

Broussonetia papyrifera invasion negatively impacted on the regenerative capacity of the Pra-Anum forest reserve. This was evident by the 335 seedlings and saplings distributed over forty-three (43) different species recorded on the uninvaded site compared to the 156 distributed over thirtyone (31) different species recorded in the invaded site. The study, however, revealed that Broussonetia invasion does not suppress the regeneration of all native species as a higher abundance of Alstonia booneiii, Celtis adolf-friderici, Cola gigantean, and Napoleonaea vogelii was recorded on the invaded site compared to the uninvaded site. The invasion of Broussonetia also exerted a negative impact on floristic 
diversity with mean Shannon and Simpson index values of $2.39 \pm 0.71$ and $0.89 \pm 0.08$ recorded on the uninvaded site compared to $1.39 \pm 0.24$ and $0.64 \pm 0.08$ on the uninvaded site. Broussonetia invasion did not only compromise species diversity but also the productivity of the forest ecosystem as mean economic tree species of $4.9 \pm 1.61$ and $13.8 \pm 1.28$ were recorded on the invaded and uninvaded sites, respectively. The study, therefore, recommends the control of the species to save the uninvaded portions of the Pra-Anum forest reserve from imminent danger of Broussonetia papyrifera invasion. Also, restoration efforts in invaded portions of the reserve could consider the use of native species belonging to the Ulmaceae and Lecythidaceae families as they appear to be resilient to the Broussonetia invasion.

\section{Data Availability}

Data used for this study is available upon request.

\section{Conflicts of Interest}

The authors declare no conflicts of interest in the content of the paper.

\section{References}

[1] M. M. Apetorgbor and P. P. Bosu, "Occurrence and control of paper mulberry (Broussoetia papyrifera) in southern Ghana," Ghana Journal of Forestry, vol. 27, no. 2, pp. 40-51, 2011.

[2] S. X. Liao, Z. H. Deng, K. Cui, Y. Z. Cui, and C. H. Zhang, "Genetic diversity of Broussonetia papyrifera populations in southwest China," Genetics and Molecular Research, vol. 13, no. 3, pp. 7553-7563, 2014.

[3] R. Obour, S. K. Oppong, and I. K. Abebrese, "Chemical composition and nutritive value of an invasive exotic species Broussonetia papyrifera in Ghana," Journal of Natural Sciences Research, vol. 7, no. 20, pp. 45-51, 2017.

[4] B. Kyereh, V. K. Agyeman, and I. K. Abebrese, "Ecological characteristics that enhance Broussonetia papyrifera invasion in a semi deciduous forest in Ghana," Journal of Ecosystems, vol. 2014, Article ID 270196, 6 pages, 2014.

[5] R. N. Malik and S. Z. Husain, "Broussonetia papyrifera (1.) l'hér. ex vent: an environmental constraint on the himalayan foothills vegetation," Pakistan Journal of Botany, vol. 39, no. 4, p. 1045, 2007.

[6] F. W. Owusu and J. K. Appiah, "Turning an invasive wood species into lumber using wood-mizer in Ghana," in Proceedings of the First National Forestry Conference Held at CSIR Forestry Research Institute of Ghana (FORIG), Ejisu, Ghana, September 2014.

[7] J. González-Lorca, A. Rivera-Hutinel, X. Moncada, S. Lobos, D. Seelenfreund, and A. Seelenfreund, "Ancient and modern introduction of Broussonetia papyrifera ((L.) vent.; moraceae) into the pacific: genetic, geographical and historical evidence," New Zealand Journal of Botany, vol. 53, no. 2, pp. 75-89, 2015.

[8] P. P. Bosu, M. M. Apetorgbor, and A. Refera, "Ecology and management of tropical Africa's forest invaders," in Invasive Plants and Forest Ecosystems, R. K. Kohli, S. Jose, H. P. Singh, and D. R. Batish, Eds., Taylor and Francis Group, Abingdon, UK, pp. 355-376, 2009.

[9] P. P. Bosu and M. M. Apetorgbor, Bronssonetia Papyrifera in Ghana. Its Invasiveness, Impact and Control Attempts, FAO, Rome, Italy, 2010.
[10] V. K. Agyeman, S. D. Addo-Danso, B. Kyereh, and I. K. Abebrese, "Vegetation assessment of native tree species in Broussonetia papyrifera-dominated degraded forest landscape in southern Ghana," Applied Vegetation Science, vol. 19, no. 3, pp. 498-507, 2016.

[11] Forestry Commission of Ghana, Management Plan for Pra -Anum Forest Reserve 2012-2022, Forestry Commission of Ghana, Akim Oda, Ghana, 2012.

[12] W. Hawthorne and N. Gyakari, Photoguide for the Forest Trees of Ghana: A Tree-Spotter's Field Guide for Identifying the Largest Trees, Oxford Forestry Institute, Oxford, England, 2006.

[13] P. Addo-Fordjour, S. Obeng, A. K. Anning, and M. G. Addo, "Floristic composition, structure and natural regeneration in a moist semi-deciduous forest following anthropogenic disturbances and plant invasion," International Journal of Biodiversity and Conservation, vol. 1, no. 2, pp. 21-37, 2009.

[14] A. Witt, T. Beale, and B. W. Van Wilgen, "An assessment of the distribution and potential ecological impacts of invasive alien plant species in eastern Africa," Transactions of the Royal Society of South Africa, vol. 73, no. 3, pp. 217-236, 2018.

[15] A. Negi, D. R. Batish, H. P. Singh, and R. K. Kohli, "Allelopathic effect of leaves of invasive tree Broussonetia papyrifera against some crop plants," Annals of Plant Sciences, vol. 5, no. 1, pp. 1261-1264, 2016.

[16] S. Abugre, E. Nyamaah, and D. Adusu, "Natural regeneration of indigenous tree seedlings under Broussonetia papyrifera stand," Journal of Energy and Natural Resource Management, vol. 5, no. 1, 2019.

[17] W. D. Hawthorne, M. Grut, and M. Abu-Juam, Forest Production and Biodiversity Conservation in Ghana, and Proposed International Support of Biodiversity Conservation, CSERGE, Norwich, UK, 1997.

[18] N. G. Swenson, "Herbaceous monocot plant form and function along a tropical rain-forest light gradient: a reversal of dicot strategy," Journal of Tropical Ecology, vol. 25, no. 1, pp. 103-106, 2009.

[19] Y. Y. Adusei, Assessment of the Natural Regeneration Potential of Reclaimed Mined Sites: Case Study of Owere Mines Limited, University of Energy and Natural Resources, Sunyani, Ghana, 2017.

[20] R. T. Shackleton, A. B. R. Witt, W. Nunda, and D. M. Richardson, "Chromolaena odorata (siam weed) in eastern Africa: distribution and socio-ecological impacts," Biological Invasions, vol. 19, no. 4, pp. 1285-1298, 2017.

[21] C. J. Krebs, Ecology: The Experimental Analysis of Distribution and Abundance, The University of British Columbia, Vancouver, Canada, 5th edition, 2001. 